\title{
The Theory/Applications Balance in Management Pedagogy: Where Do We Stand?
}

\author{
Daniel A. Wren, \\ M. Ronald Buckley, \\ Larry K. Michaelsen \\ University of Oklahoma
}

\begin{abstract}
Business schools are expected to be "professional" in the sense that their mission is primarily to prepare people to practice their skills in the business world. Various critics, however, claim that management professors overemphasize theory and research and neglect the practice and applications students need to transfer classroom theory to the world of practice. This study compared an earlier sample with a more recent sample of Academy of Management members concerning the relative emphasis they believed should be placed on theory and applications in management pedagogy and the techniques they used to bring applications into the classroom. Current respondents believed that more emphasis should be placed on applications than the earlier respondents. An unexpected finding, however, was that the more recent respondents reported a lower mean usage of pedagogical techniques that are appropriate for developing students' ability to apply course concepts than the previous group. Possible reasons for these incongruent findings are discussed as well as the implications for management pedagogy.
\end{abstract}

\section{The Criticisms of Current Practices in Management Education}

Business schools are expected to be "professional" in the sense that their mission is primarily to prepare people to practice their skills in the business world. In examining the literature, however, there are sentiments among both educators and business leaders that business schools and/or management professors overemphasize research, theory, and quantitative analysis in order to achieve academic respectability at the expense of not producing managers who are equipped for the practice of management. Critics claim that analytic rigor to please other scholars has achieved preeminence over relevance to those who practice. Leavitt (1989) claims an overemphasis on analytical skills to the 
neglect of innovation and path finding while Behrman and Levin charge that academicians focus on research which "would fail any reasonable test of applicability or relevance to consequential management problems or policy issues ... [and] ignore any utility to managers or business organizations" (1984, p. 141). Numerous others (Bickerstaffe, 1981; Mandt, 1982; Miles, 1985; Muller, Porter, \& Rehder, 1988; Waddock, 1991) criticize business schools as overemphasizing quantification, specialization, and as being irrelevant to the world of practice. Academic intransigence, the publish or perish syndrome, faculty complacency, and poor preparation of those who are to teach are among the reasons given for this gap between theory and practice. Oviatt and Miller (1989) blame the structure of business education, the tradition of academic freedom, and the academic reward system for the intransigence of professors with respect to relevance in business education.

The American Assembly of Collegiate Schools of Business (AACSB) sponsored a three year comprehensive study of business education which surveyed deans, faculty, alumni, provosts, business persons who served on advisory councils to business schools, and selected corporate personnel (Porter \& McKibbin, 1988). Porter and McKibbin found a "general level of complacency about the basic thrust and nature of the present curriculum" ( $p$. 81 ) and noted that managers need a breadth of knowledge and the ability to integrate various disciplines yet the preparation of those who are to teach management is narrow, specialized, and does not provide them with the ability to relate to realistic management problem solving situations. Porter and McKibbin expressed concern that new Ph.D.s joining business school faculties lacked a sufficient breadth of understanding of real-world business problems and were unable to appreciate the complexities and subtleties of business. This problem was "exacerbated ... by the increasing number of faculty members trained in other disciplines who do not even have the benefit of a business school socialization process" (p. 326).

While Porter and McKibbin dealt with both graduate and undergraduate education, the results of a Graduate Management Admission Council (GMAC) study contended that: "In the research and teaching emphases that currently prevail on many campuses, some see the pedantic sterility of a second-class science - one that is too refined to be applied to the problems of a society as complex as ours ..." $(1990$, p. 20$)$. The GMAC report called for a new synthesis of "academic rigor and managerial relevance" which would not be easy because present practices in "doctoral programs and tenure and promotion policies appear to overvalue academic rigor and undervalue relevance to the practice of management" (GMAC, 1990, p. 37).

\section{Attempts to Improve the Transfer of Learning}

Concern for making classroom theory relevant to the practice of management has led to a movement for skill development in the application of knowledge. Mintzberg noted that "skill training will be-and probably should be-the new revolution in management education" (1973, p. 193). Educators (e.g., Bloom, 1956; Serey \& Verderber, 1991), cognitive psychologists (e.g., 
Anderson, 1982; 1983), and others (Gagné, 1965; 1985), have convincingly argued that there are different levels of cognitive processes. The least complex involves being able to identify and recall factual information about something. This factual part of learning has appeared under various labels: "declarative knowledge"(Anderson, 1982; 1983); "knowledge"(Bloom, 1956); and "content" (Waters, 1980). A more complex level of learning occurs when individuals are capable of the cognitive activity of acting on their knowledge. This applications part of learning has also appeared under different terms: "procedural knowledge"(Anderson, 1982; 1983); "application"(Bloom, 1956); and "process" (Waters, 1980).

The competency based management education movement (CBME) for example, focuses on knowledge acquisition as well as on what students can do with that knowledge (Albanese, 1989; Keys \& Wolfe, 1988; Wexley \& Baldwin, 1986). Albanese believes that "management schools can have a significant influence on management practice only when the students are given opportunities to learn and practice skills and to receive constructive feedback from someone who understands the skills" $(1989$, p. 17). The overriding notion in CBME is that students need to acquire knowledge about management and have opportunities for skill assessment, practice, and application (e.g., see Quinn, Faerman, Thompson, \& McGrath, 1990; Whetten \& Cameron, 1991). As a result, a key determinant of the impact of management education course work is the extent to which instructors recognize the importance of going beyond learning about management concepts by: (1) focusing their teaching on how the concepts apply to "real world" settings; and (2) providing students with the opportunity to practice using the concepts in a variety of workplacelike settings.

Further, a large body of literature on the transfer of learning suggests that students' ability to use the concepts to deal with problems they will face in the workplace is clearly influenced by the pedagogical techniques employed by their instructors (e.g., Gagné, 1985). In their analysis of the effectiveness of managerial training, Burke and Day found that "multiple techniques are highly likely to lead to positive training results ... [and] improving learning across situations as measured by subjective learning criteria" (1986:242). For example, lecturing about concept applications is likely to have little, if any, impact on students' ability to use the concepts in their future jobs unless other learning techniques are used. Thus, developing students' ability to transfer their learning from the classroom to the workplace requires both an emphasis on content applications and the use of teaching approaches and activities that allow students to practice using the concepts in situations that are as similar as possible to their future work environments. Baldwin and Ford posit a "principle of identical elements" that predicts the transfer of learning will be optimized when "there are identical stimulus and response elements on the training and transfer settings." (1988, p. 86). The use of multiple teaching techniques increases the likelihood that a transfer of learning will occur and can be used to supplement theory.

Using data collected in an earlier survey as a baseline (Wren, Atherton, \& Michaelsen, 1980), this study focused on an examination of what changes, 
if any, may have occurred in management education during the intervening period that would be likely to affect the preparation of current and future management graduates as they enter the job market. Further, the study examines the most important elements of the management education processmanagement instructors, their beliefs about what should be taught, the methods they use in their teaching, and the way they have been influenced by their own doctoral education.

The current study was aimed at answering three research questions:

1. Has there been a change in management educators' beliefs with respect to what should be the relative emphasis of applications vis á vis theory?

2. Has there been a change in the use of educational approaches that are appropriate for applying the kind of skills that business school graduates have been seen as lacking?

3. What is the impact of increasing numbers of non-business trained management educators on the education process (Porter \& McKibbin, 1988)?

\section{Method}

\section{Population}

The population selected for study was the Academy of Management membership on the assumption that it is the most representative group of those who teach and do research in management at the university level. The survey instrument (see Appendix A) was pretested on a group of management teachers, revised, and mailed first-class to a random sample of 2,000 United States and Canadian Academy of Management members who were listed in the 1988-1989 membership directory. A postage paid preaddressed return envelope was provided. Six hundred twenty two responses were returned for a 31 percent return rate. Of these, 519 were usable which translates into a response rate of 26 percent. Seventeen of our unusable responses were from persons in nonacademic positions who could not comment on the theory/applications orientation in management courses; 59 did not teach management but were in marketing, sociology, or psychology; and 26 just returned blank questionnaires.

The mean age of the respondents was 39.9 years. The highest degrees obtained were Ph.D., 85 percent; Masters, 13 percent; and Bachelors, 2 percent. With respect to recency of degrees, 18 percent were received in the past 5 years and 37 percent within the past 10 years. The mean for the year of receiving the doctoral degree was 1977; the modal year was 1983. As to rank, 33 percent were full professors, 30 percent were associate professors, 28 percent were assistant professors, 6 percent were instructors, and 3 percent were graduate assistants. Seventy eight percent were male; 22 percent were female.

In an attempt to check for nonrespondent bias we compared our respondents with a survey of Academy of Management members ("Results of the Membership Survey," 1988, pp. 3,7) and found they were highly similar in rank, highest degree received, years of academic experience, and years of 
business/government experience. We concluded that our 1989 respondents were representative of Academy of Management members who responded to the most current survey of the membership.

We also compared the respondents of the more recent survey with those surveyed earlier and found they were almost identical with respect to highest degree attained, recency of degree, and rank. The most pronounced changes were in age, 39.9 versus 43.5 years previously; in the male/female distribution of 78 percent male currently versus 95 percent earlier, and 22 percent female presently compared with 5 percent earlier; and managerial experience of 11.7 years earlier compared with 7 years more recently.

\section{Procedures}

Data on the teaching orientation of management professors were obtained from responses to the question, "In the courses you teach frequently (more than once in the last three years), what do you think the appropriate balance between theoretical concepts and practical applications is to provide maximum value to students in the following courses at the undergraduate and graduate levels?" Respondents were given a list of 9 courses commonly found in management: Principles, Production/Operations Management, Organization Theory, Business Policy/Strategy, Labor Relations, Organizational Behavior, Management Information Systems, Human Resource Management, and Business and Society/Ethics. Compared with the earlier survey, the titles of some courses were changed to reflect more current content: from "Business Policy" to "Business Policy/Strategy"; from "Personnel Management" to "Human Resource Management"; and from "Business and Society" to "Business and Society/Ethics." "Operations Research" was dropped from the list of courses. Otherwise, the courses proffered were the same as those in the previous survey. A 7-point scale was provided which ranged from 1 ("almost all theory"), to 4 ("equal emphasis"), to 7 ("almost all application"). Respondents were asked to check the value which indicated their belief about the appropriate balance for each course at the undergraduate and graduate levels.

A theory/applications orientation index was computed for both graduate and undergraduate courses by calculating the mean score for all courses at each level. Both indices were highly reliable (coefficient alpha $=.86$ for the undergraduate application orientation and .83 for graduate application orientation), and were minimally correlated with each other $(r=.09 p<.05)$. Data were also collected on managerial experience, nonmanagerial experience, rank, degree field of highest degree, age, and size of the institution where they were employed. These procedures were the same as those in the previous survey.

The respondents were also asked to report on the strategies they used to bring practical applications into their teaching. The respondents were then given some commonly used techniques: (1) personal experiences; (2) management case analysis; (3) off-campus assignments; (4) experiences of students; (5) computer simulations; (6) experiential exercises; (7) audio-visual training materials; (8) guest speakers; and (9) "other" which provided a space for respondents to write in other techniques. These techniques were the same as those surveyed in the 
earlier study except "off-campus assignments" and "guest speakers" were added as possibilities. A 7-point scale was provided which ranged from 1 ("seldom or never"), 3 ("occasionally"), 5 ("often"), to 7 ("a great deal"). Respondents were asked to select a value on the scale which reflected the extent to which they used these means of bringing applications into teaching.

\section{Results}

\section{The Balance between Theory and Applications}

Research Question 1 asked if there had been any changes in management educators' beliefs with respect to what should be the relative emphasis on applications vis á vis theory between the earlier and the most recent study? We provided a seven point scale which asked our respondents to indicate their belief about the appropriate balance for each course at the graduate and undergraduate levels. The relative emphasis the respondents believed should be placed on the balance between theoretical concepts and practical applications is outlined in Table 1. Respondents reported believing that a greater emphasis should be on theory in graduate courses than in undergraduate courses. In order to examine the differences between the two surveys, Z-scores were calculated (Allen \& Yen, 1979; Heinze, 1980). Our decision to utilize a Z-scores analysis when comparing 1979 data with 1989 data was motivated by our desire to standardize scores over the 12 year longitudinal period. Although our sample sizes were so large that the $Z$ distribution closely approximated $t$ distribution, we felt more comfortable using the standardized scores. This analysis indicated that differences between graduate and undergraduate courses were significant at the .05 level with the exception of Business and Society/Ethics, Management Information Systems, and Labor Relations, suggesting that instructors made little distinction between theory and applications between the undergraduate and graduate levels in the above subjects or, possibly, that these subject areas possess a less developed theory base than other subjects included in this survey.

With " 4 " as the mid-point on the scale where theory and applications receive equal emphasis, the data show that instructors believe that undergraduate courses should receive more emphasis on applications (mean=4.76); that graduate courses should be somewhat less applications oriented (mean $=4.40)$; while there is an overall tendency toward applications (mean=4.58). A two-way analysis of variance indicated significant differences between courses $(F=86.8 p<.05)$ and between graduate and undergraduate levels of instruction $(F=47.3 p<.05)$.

Compared with the previous survey, instructors in 1989 believe there should be more emphasis on applications: the mean for all courses earlier was 4.13, but more recently this mean was 4.58 indicating more emphasis on applications in management pedagogy. At the undergraduate level the earlier mean equalled 4.25 and the more recent mean was 4.76; at the graduate level the previous mean was 4.02 and in the current survey the mean equalled 4.40. Significant changes occurred for Principles of Management, Production/Operations Management, 
Table 1. A Z-Score Comparison of 1977 and 1989 Survey Results for The Theory/Applications Orientation ${ }^{\mathrm{a}}$

\begin{tabular}{|c|c|c|c|c|c|c|}
\hline \multirow[b]{2}{*}{ Course/Subject Matter } & \multicolumn{2}{|c|}{ Undergraduate } & \multirow[b]{2}{*}{ Z-Score } & \multicolumn{2}{|c|}{ Graduate } & \multirow[b]{2}{*}{ Z-Score } \\
\hline & $1977^{\circ}$ & $1989^{c}$ & & $1977^{\mathrm{b}}$ & $1989^{\mathrm{c}}$ & \\
\hline Principles of Management & 3.86 & 4.23 & $3.97^{*}$ & 3.59 & 3.78 & $2.04^{*}$ \\
\hline Production/Operations Management & 4.44 & 4.65 & $2.25^{*}$ & 4.13 & 4.03 & 1.07 \\
\hline Organization Theory & 3.36 & 4.12 & $8.17^{*}$ & 3.10 & 3.58 & $5.16^{*}$ \\
\hline Business Policy/Strategy & 4.86 & 5.01 & 1.61 & 4.70 & 4.75 & .53 \\
\hline Labor Relations & 4.69 & 4.75 & .64 & 4.52 & 4.63 & 1.18 \\
\hline Organizational Behavior & 4.03 & 4.12 & .96 & 3.75 & 3.58 & 1.82 \\
\hline Management Information Systems & 4.34 & 5.37 & $11.07^{*}$ & 4.11 & 5.29 & $12.6^{*}$ \\
\hline Human Resources Management & 4.64 & 5.13 & $5.26^{*}$ & 4.38 & 4.62 & $2.58^{*}$ \\
\hline Business and Society/Ethics & 4.22 & 5.42 & $12.90^{*}$ & 4.06 & 5.30 & $34.8^{*}$ \\
\hline
\end{tabular}

Notes: ${ }^{a}$ A lower value reflects more emphasis on theory, while a higher value reflects more emphasis on applications.

Critical $\mathrm{Z}$ value where $\mathrm{a}=.05$ are \pm 1.96

${ }^{*} p>.05$

${ }^{b} N=1,243$.

${ }^{c} N=519$.

Organization Theory, Management Information Systems, Human Resources Management, and Business and Society/Ethics.

At the graduate level, instructors in 1989 believe there should be more emphasis on applications in all courses except for Production/Operations Management and Organizational Behavior. The graduate courses with instructor beliefs about significant changes in emphasis toward applications were Principles of Management, Organization Theory, Management Information Systems, Human Resources Management, and Business and Society/Ethics, the same subject areas as those at the undergraduate level, except for Production/Operations Management.

Contrary to the critics' expectations, our more recent respondents believed there should be more of an applications orientation than those in the previous survey. If " 4 " reflects an equal theory/applications balance, the later respondents perceive themselves to be on the applications side of the teetertotter for all undergraduate courses and on the applications side at the graduate level for all but 3 courses (Principles of Management, Organization Theory, and Organizational Behavior).

\section{Pedagogical Techniques Used}

Research Question 2 asked if there has been a change between the early study and the more recent one concerning approaches or techniques used by the instructor to apply their classroom theory? We provided a list of frequently used pedagogical techniques and asked our respondents to identify the techniques they used to bring in applications and, on a seven point scale, to indicate the frequency of use of these techniques. The pedagogical techniques used by the respondents to illustrate applications are shown in Table 2. These 
Table 2. A Z-Score Comparison of Reported Usage of Pedagogical Techniques Used to Focus on Applications ${ }^{a}$

\begin{tabular}{|c|c|c|c|c|}
\hline \multicolumn{2}{|c|}{ Technique } & $1977^{b}$ & $1989^{\mathrm{c}}$ & Z-Score \\
\hline \multicolumn{2}{|c|}{ Personal Experience } & 5.35 & 4.56 & $4.93 *$ \\
\hline \multicolumn{2}{|c|}{ Cases } & 4.59 & 4.02 & $3.56^{*}$ \\
\hline \multicolumn{2}{|c|}{ Experiential Exercises } & 3.85 & 3.26 & $3.68^{*}$ \\
\hline \multicolumn{2}{|c|}{ Experiences of Students } & 3.76 & 3.27 & $2.81^{*}$ \\
\hline \multicolumn{2}{|c|}{ Audio-visual } & 3.20 & 2.78 & $2.62^{*}$ \\
\hline \multicolumn{2}{|c|}{ Computer simulations } & 2.34 & 1.87 & $2.93^{*}$ \\
\hline ote & $\begin{array}{l}\text { "A lower value refl } \\
\text { e.g. where "3" me } \\
\text { a } 7 \text { point scale. } \\
\text { Critical Z value n } \\
\text { * } p<.05 \\
\text { b } N=1,243 . \\
\text { " } N=519 .\end{array}$ & $\begin{array}{l}\text { lower me } \\
\text { ccasional } \\
=.05 \mathrm{are}\end{array}$ & $\begin{array}{l}\text { of a pa } \\
\text { le "5" }\end{array}$ & $\begin{array}{l}\text { r techniq } \\
\text { "often" }\end{array}$ \\
\hline
\end{tabular}

data allow us to make comparisons with the previous study. The data show that professors rely a great deal on their personal experiences. The respondents reported a mean of 7 years of managerial experience; however, 19.3 percent of these recent respondents reported no managerial experience. In the earlier study, 10.5 percent of the respondents reported no managerial experience and this difference between the surveys highlight the decline of experience over this time period (see Buckley, Wren, \& Michaelsen, 1992). Cases, experiential exercises, and students' experiences are also extensively used, while guest speakers and computer simulations are less frequently used.

Compared to the previous survey, however, there has been a significant decline in the mean usage of all techniques. This finding was inconsistent with our results from Research Question 1. Our recent respondents believed there should be more of an applications orientation than our previous group but reported a lower usage of techniques which are commonly used to bring applications into the classroom.

\section{Academic Background of the Respondents}

Research Question 3 was based on Porter and McKibbin's (1988) observations of an increasing number of non-business school educated management professors. We gathered information about the doctoral degree field disciplines and examined their theory/applications orientation. A large portion of our more recent sample - approximately one-third-were trained in non-business disciplines. Two questions are germane: (1) Does the same theory/ applications orientation exist for both business and non-business graduates; and, (2) are applications used to the same extent by business and non-business graduates? As can be seen in Table 3, $t$-tests reveal that there are no significant differences in the beliefs expressed about what the theory/applications orientation should be between the business and non-business doctoral degree recipients. A $t$-test was used as there were no violations of the assumptions of 


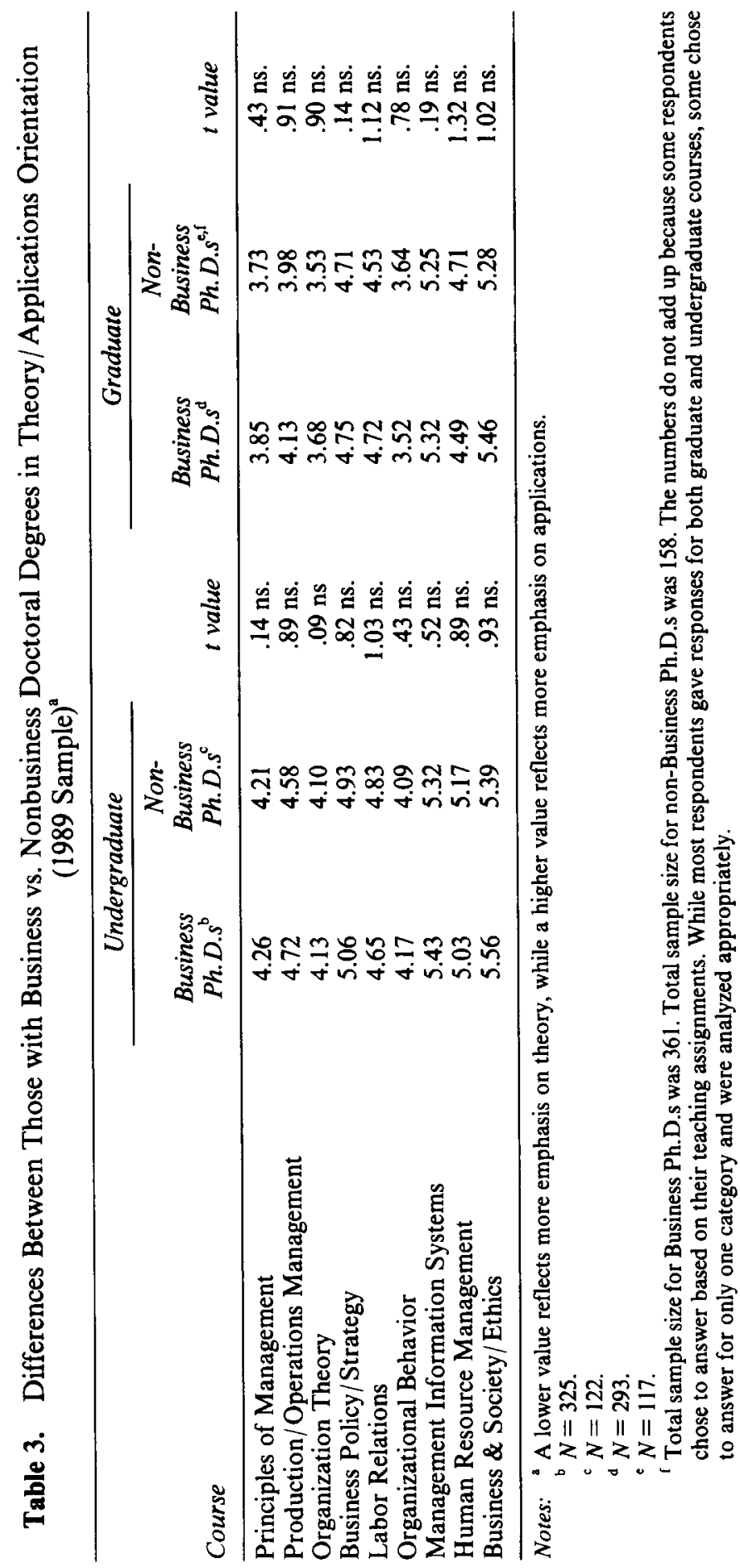

JOURNAL OF MANAGEMENT, VOL. 20, NO. 1, 1994 
Table 4. Differences Between Those with Business vs.

Nonbusiness Doctoral Degrees in Reported Usage of Pedagogical Techniques

(1989 sample)

\begin{tabular}{lccc}
\hline Technique & $\begin{array}{c}\text { Business } \\
\text { Ph.D.s }\end{array}$ & $\begin{array}{c}\text { Nonbusiness } \\
\text { Ph.D.s. }\end{array}$ & $t$ value \\
\hline Personal Exp. & 5.36 & 4.18 & $3.63^{*}$ \\
Cases & 4.58 & 3.61 & $2.76^{*}$ \\
Experiential Exercises & 3.29 & 3.23 & .16 \\
Experiences of Students & 3.98 & 2.59 & $4.50^{*}$ \\
Audio-Visual & 3.28 & 2.43 & $2.18^{*}$ \\
Computer Simulation & 1.93 & 1.85 & .42 \\
\hline
\end{tabular}

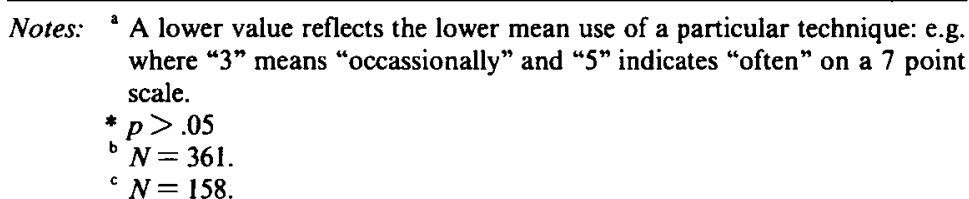

$t$ (normal distribution, homogeneity of variance). Apparently, these respondents have similar perceptions regarding the optimal theory/applications balance which should occur.

In terms of the application techniques which are utilized by those from business versus non-business disciplines, however, a number of differences occur (see Table 4). For all of the techniques surveyed (except experiential exercises and computer simulation), those with non-business doctoral degrees reported a significantly lower level of usage of techniques to bring applications into their teaching than their business-degreed counter-parts. While their beliefs about the theory/applications orientation are similar to that reported by business respondents, non-business school trained respondents report less frequent use of techniques appropriate for enabling students to apply course concepts to real world settings.

\section{Discussion and Conclusions}

We were not surprised to find that, compared to the previous study, professors believed that more emphasis should be placed on applications vis á vis theory. In fact, we would have been surprised if the persistent criticisms aimed at management education had not produced this sort of a shift in instructors' teaching. We were surprised, however, that the more recent respondents reported substantially less frequent use of virtually all of the teaching methods that we thought might be used to focus on applications than respondents in the earlier study. In order to ferret out why these apparently incongruous findings occurred, we considered several alternative explanations. 


\section{Are There Other Methods for Bringing in Applications?}

One possible explanation for our incongruous findings was that respondents were using methods other than those listed on our questionnaire instrument to bring an applications focus to their teaching. We listed a number of approaches for actively involving students (see Table 2) and provided an "other" column, which was used by less than two percent of the respondents. To probe for respondent lethargy in responding under the "other" category, we contacted a number of colleagues in order to determine any other possibilities that were not included. Our colleagues identified two pedagogical techniques that we had not included in the survey: (1) the use of practitioner oriented periodicals such as Business Week, Fortune, etc.; and (2) the trend toward more supplementary materials being provided with texts such as video cassettes, illustrative vignettes of organizational events, and so on. Some may not have considered these to be "cases" in the traditional business school sense but as illustrations and/or applications to be presented to the students.

\section{Beliefs vs. Behaviors}

The nature of the questions we asked were different: one asked for a statement of belief about what should be the appropriate balance between theory and applications while the second question asked for the techniques they used to bring applications into the classroom. In the first question, it is possible that the instructors provided a response that they felt was socially and/or professionally appropriate, considering the criticisms about management education being too theoretical. The second question, however, asked about behaviors, not beliefs, and would not be as susceptible of being influenced by the need to respond in a socially and/or professionally desirable manner. The incongruity could therefore be due to our method of asking the questions: one, a statement of belief, and the other asking for action oriented behaviors.

\section{Doctoral Training of the Respondents}

Another possible explanation was the doctoral training of our respondents. Our respondents' perceptions of their own teaching was undoubtedly influenced by their experience as students and, given the research oriented nature of doctoral programs coupled with their non-business backgrounds, they very likely spent a great deal more time working with theory than they did with applications. As a result, our non-business school respondents may well have reported similar beliefs in the appropriateness of emphasizing applications but behaved quite differently than their business school trained colleagues. The discrepancies in our results may have been primarily a result of differing frames of reference between our business school and non-business school respondents. If so, this may help explain the incongruous findings concerning a belief there should be more of an applications orientation accompanied by a decline in techniques used to bring applications into the classroom since much of the growth of Academy of Management membership since the earlier survey has been from non-business school disciplines. 


\section{Summary and Implications}

Some have asserted that management education is too theoretical and adrift from the practice of management. One purpose of this survey was to assess the theory/applications balance according to the beliefs of recent respondents and to compare those responses with those obtained in a similar earlier survey. More recent respondents believe that they should place a greater emphasis on applications than the previous respondents. In terms of the use of pedagogical techniques to bring applications to the students, however, our recent respondents reported a lower mean usage than our previous respondents.

Regardless of the reasons for the incongruity between our respondents' beliefs and their teaching practices, we are concerned that the less frequent use of these techniques may lead to a decrease in students' ability to transfer their learning from the classroom to the workplace. Further, our data indicated that professors were attempting to bring applications into their teaching primarily by relating managerial concepts to their personal experiences. If so, that approach would seem to be educationally unsound for at least two reasons. First, given their reduced experience base, instructors' examples are likely to be simplistic and/or second-hand. Second, expecting students to learn to apply concepts by listening to someone else's examples would be like expecting them to be able to ski after having watched the Winter Olympics on television. There is a near consensus in the education literature that listening alone simply isn't an active enough learning process to foster the development of higher level cognitive skills ( e.g., Bloom, 1956; Gagné, 1965; 1985). Adequately preparing students for their future jobs requires giving them the opportunity to practice using course concepts in stimulus situations that are of roughly the same level of complexity as their future work settings ( e.g., Gagné, \& Briggs, 1979, pp. 335-339) and providing "identical elements" to facilitate the transfer of learning (Baldwin \& Ford, 1988).

Our results suggest that teachers of management are not emphasizing how to apply knowledge as much as they, the instructors, think they should. Those who criticize how we prepare our students for their professional careers may be on target, suggesting that we need to take heed of their admonitions. If this is the situation, then there is a greater need to develop and/or promote teaching techniques that foster active learning in applications.

The implication of these results is that neither our respondents' doctoral programs nor their nonacademic work experience has provided them with the kind of a reality anchor that was more typical of their counterparts a decade ago. Further, unless there are active steps to reverse the trend, the external criticisms of the lack of relevance in management education is likely to increase. To preclude this situation, some short run strategies might include developing professors' instructional skills by encouraging and supporting their attendance at conferences and providing access to journals which focus on ways to bring applications into the classroom (Buckley, Wren, \& Michaelsen, 1992). Long term change, however, will probably require a re-examination of the way 
doctoral students are selected and socialized (AACSB, 1991; Payne \& Brennan, 1990), and/or in the academic reward systems so that they encourage rather than discourage faculty members to increase their awareness of the issues facing managers in the workplace.

Within the recent past an apparent shift in beliefs about the prevailing theory/ applications balance and in pedagogical techniques has occurred. The shift in beliefs toward applications was expected based on the literature and other developments such as competency based management education. The decline in the use of applications oriented techniques, however, was not expected. There is an incongruity between the beliefs of our more recent respondents and the use of techniques to bring applications into the classroom. The reported beliefs are that there should be a greater emphasis on applications, yet there is a decline in the use of techniques to accomplish this. Demographic changes (training in non-business school disciplines, being younger, and having less managerial experience), as well as some of other possible factors, appear to have contributed to this decline. Transfer of learning theory and research suggest that academicians can significantly influence the practice of management by providing opportunities for students to apply and practice the theory they receive. Our research suggests that we think we are offering applications to accompany theory but the evidence is that we are providing fewer opportunities for practice than we think.

Acknowledgment: The authors wish to thank the Center for Economic and Management Research, the Research Council of the University of Oklahoma, and the Noble Foundation of Ardmore, Oklahoma, for the financial and other support provided for this research. We are also indebted to three anonymous reviewers for their helpful comments and constructive insights.

\section{Appendix A}

Dear Colleague:

We are interested in learning how the managerial and non-managerial experiences of Academy of Management members relate to their views with respect to the content and teaching of various courses. We would appreciate your cooperation in completing and returning the following questionnaire. A post-paid return envelope is enclosed for your convenience.

Your questionnaire is numbered for control purposes only. No report will be made which would connect your responses with your identity.

1. In the courses you teach frequently (more than once in the last three years), what do you think the appropriate balance between theoretical concepts and practical applications is to provide maximum value to students in the following courses at the undergraduate levels? (Find the number which reflects your views and insert it in the appropriate blank(s) at the appropriate level.) 


\begin{tabular}{|c|c|c|}
\hline $\begin{array}{c}\text { Almost All } \\
\text { Theory }\end{array}$ & $\begin{array}{l}\text { Equal Emphasis } \\
\text { to theory and } \\
\text { Application }\end{array}$ & $\begin{array}{l}\text { Almost All } \\
\text { Application }\end{array}$ \\
\hline
\end{tabular}

Course or Subject Area

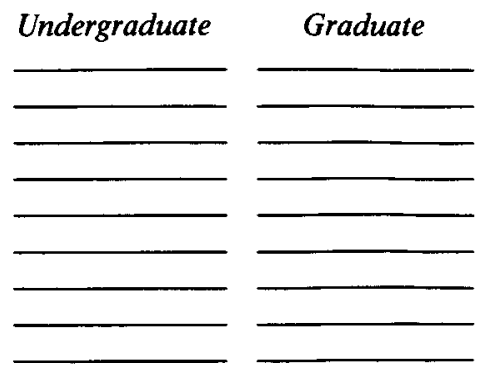

a. Principles of Management

b. Production/Operations Management

c. Organization Theory

d. Business Policy/Strategy

e. Labor Relations

f. Organizational Behavior

g. Management Information Systems

h. Human Resource Management

i. Business and Society/Ethics

2. When you attempt to bring applications into your teaching, to what extent do you utilize the following sources? (Enter the number in the spaces provided below.)

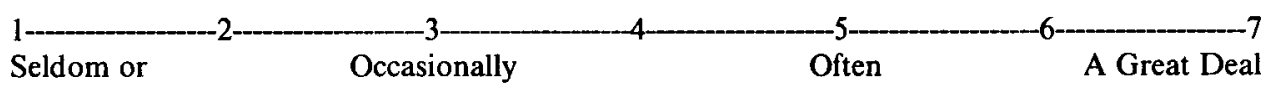

Never

a. Use management case analysis

b. Relate your personal expeiences

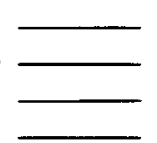

f. Use computer simulations

g. Use experiential exercises

c. Rely on experiences of students

h. Use audio-visual training

d. Make off-campus assignments materials to students

i. Other

e. Utilize guest speakers

(Specify)

3. How many years of experience (full-time equivalent) have you had as a manager in each of the following kinds of organizations? (For fractions of years, round to the nearest whole number.)

\begin{tabular}{lllll}
\multicolumn{2}{c}{ Prior to 1989} & \multicolumn{2}{c}{1980 to Date } \\
$\begin{array}{c}\text { Non- } \\
\text { Managerial } \\
\text { Managerial }\end{array}$ \\
$\begin{array}{l}\text { Business } \\
\text { Military } \\
\text { Public Sector } \\
\begin{array}{l}\text { Academic } \\
\text { Consulting } \\
\text { Other (describe) }\end{array}\end{array}$ & - & - & - \\
\end{tabular}

4. To what extent do you believe that managerial experience does/would improve the quality of your research?

None $\quad$ Very Little $\quad$ Of Some Benefit $6-7$


5. To what extent do you believe that managerial experience does/would improve the quality of your teaching?

None $\quad$ Very Little $2-4-6-7$ Of Some Benefit

6. To what extent do the administrators in your department/college believe that managerial experience improves/would improve the quality of your research?

None $\quad$ Very Little $4-6-6-3$ A Great Deal

7. To what extent do the administrators in your deprtment/college believe that managerial experience improves/would improve the quality of your teaching?

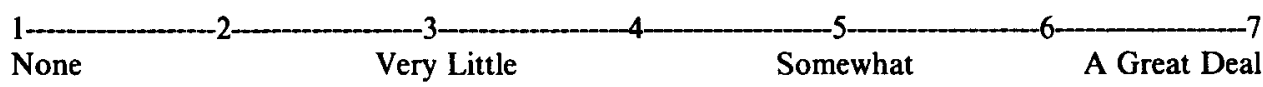

8. To what extent do the administrators in your department/college provide you with opportunities for you to gain managerial experience?

None $\quad$ Very Little $3-4-5-6$ Often

9. If you decide to invest a share of your time in gaining managerial experience, to what extent would your department/college administrators reward you?

None $\quad$ Very Little $3-6-5$ To Some Extent 4

10. Check your rank:

Professor

Associate Professor

Assistant Professor

11. Current administrative position:

None

Dean (or Assistant or

Associate Dean)

Department Head

12. Highest academic degree obtained:

Bachelor's

Master's
Instructor

Graduate Assistant

Other (specify) 
13. Degree field of highest degree and year obtained:

(field)

(year)

14. Your age:

15. Sex: Male Female

16. The type of institution in which you teach:

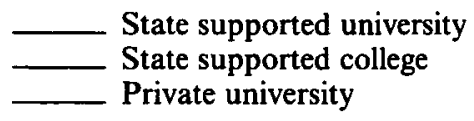
Private college Non-academic or non-teaching Other (specify)

17. Approximate number of students in your institution:
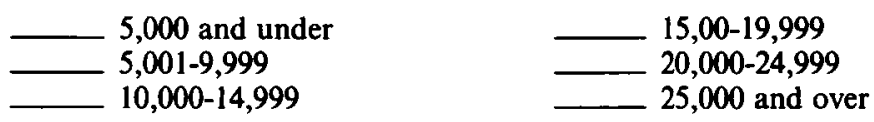

Thank you for helping us in our research. Please return the questionnaire in the post-paid addressed envelope.

\author{
Michael R. Buckley \\ Larry K. Michaelsen \\ Daniel A. Wren
}

\title{
References
}

Albanese, R. (1989). Competency-based management education. Three operative and normative issues. The Organizational Behavior Teaching Review, 14(1):16-28.

Allen, M. \& Yen, W. (1979). Introduction to measurement theory. New York: Brooks-Cole Publishers.

American Assembly of Collegiate Schools of Business. (1991, April 23). Final report, the AACSB accreditation project. Unpublished document, AACSB.

Anderson, J.R. (1982). Acquisitioning cognitive skill. Psychological Review, 89:369-406.

(1983). The architecture of cognition. Cambridge, MA: Harvard University Press.

Baldwin, T.T. \& Ford, J.K. (1988). Transfer of training: A review and directions for future research. Personnel Psychology, 41: 63-105.

Behrman, J.N. \& Levin, R.I. (1984). Are the business-schools doing their job? Harvard Business Review, 62(January/February): 140-147.

Bickerstaffe, G. (1981). Crisis of confidence in the business-schools. International Management, 36(8):1923.

Bloom, B.S. (1956). Taxonomy of educational objectives: Cognitive and affective domains. New York: David McKay Co.

Buckley, M.R., Wren, D.A., \& Michaelsen, L.K. (1992). The role of managerial experience in the management education process: Status, problems, and prospects. Journal of Management Education, I6(3): 303313.

Burke, M.J. \& Day, R.R. (1986). A cumulative study of the effectiveness of managerial training. Journal of Applied Psychology, 71:232-245.

Gagné, R.M. (1965). The conditions of learning. New York: Holt, Rinehart, \& Winston. (1985). The conditions of learning and theory of instruction, 4th ed. New York: Holt, Rinehart \& Winston.

Gagné, R.M. \& Briggs, L.R. (1979). Principles of instructional design, 2nd ed. New York: Holt, Rinehart \& Winston. 
Graduate Management Admissions Council. (1990). Leadership for a changing world: The future role of management education. Los Angeles, CA: Report of the Commission on Admission to Graduate Management Education, Graduate Management Admissions Council.

Heinze, D. (1980). Fundamentals of managerial statistics. Cincinnati, OH: South-Western Publishing Co.

Keys, B. \& Wolfe J. (1988). Management education and development: Current issues and emerging trends. Journal of Management, 14: 205-229.

Leavitt, H. J. (1989). Educating our MBAs: On teaching what we haven't taught. California Management Review, 3I(3): 38-50.

Mandt, E. J. (1982). The failure of business education-and what to do about it. Management Review, 7I(8): $47-52$.

Miles, R. E. (1985). The future of business education. California Management Review, 27(3): 63-73.

Mintzberg, H. (1973). The nature of managerial work. New York: Harper \& Row.

Muller, H. J., Porter, J. L., \& Rehder, R. R. (1988). Have the business schools let down U.S. corporations? Management Review, 77(10): 24-31.

Oviatt, B. M. \& Miller, W. D. (1989). Irrelevance intransigence, and business professors. Academy of Management Executive, 3: 304-312.

Payne, S. L. \& Brannen, D. E. (1990). Doctoral programs in management and business administration: Investigation of criticisms and reforms. Organizational Behavior Teaching Review, 14(3): 1-13.

Porter, L. \& McKibbin, L. E. (1988). Management education and development: Drift or thrust into the 21st century? New York: McGraw-Hill.

Quinn, R. E., Faerman, S. R., Thompson, M. P., \& McGrath, R. M. (1990). Becoming a master manager: A competency framework. New York: Wiley.

Results of the membership survey. 1988. Academy of Management Newsletter, 18(January): 3,7.

Serey, T. T. \& Verderber, K. S. (1991). Beyond the wall: Resolving issues of educational philosophy and pedagogy in the teaching of management competencies. Pp. 3-19 in J. D. Bigelow (Ed.), Managerial skills: Explorations in practical knowledge. Newbury Park, CA: Sage.

Waddock, S. A. (1991). Educating tomorrow's managers. Journal of Management Education, 15(1): 69-95.

Waters, J. A. (1980). Managerial skill development. Academy of Management Review, 5: 449-453.

Wexley, K. N. \& Baldwin, T. T. (1986). Management development. Journal of Management, 12: $237-294$.

Whetten, D. A. \& Cameron, K. S. (1991). Developing management skills, 2nd ed. Glenview, IL: Scott, Foresman.

Wren, D. A., Atherton, R. M., \& Michaelsen, L. K. (1980). Theory and applications in management pedagogy: An empirical study. Journal of Management, 6: 21-31. 